\title{
SLOVENE PROVERBS THROUGH THE TIME
}

\author{
Marija STANONIK \\ ISN ZRC SAZU, 1000 Ljubljana, Novi trg 5, Slovenija
}

\begin{abstract}
The paper focuses on Slovene researchers' interest in Slovene proverbs from the Slovene Protestantism (about 1550) to the present time. The first proverbs are found in the written form already with the founder of the Slovene written language Primož Trubar. It was the grammarian Adam Bohorić, who first systematically included the proverbs in the first Slovene grammar book in 1568. The first collection of Slovene proverbs was prepared by Janez Mihelić, but it was lost already at the end of the 18th century. In the second half of the 19th century a lot of cultural workers collected Slovene proverbs at the same time as the words for The Dictionary of Slovene Language. But only Fran Kocbek published proverbs in a separate book in 1887. In the first half of the 20th century the most productive collector was Josip Saselj, who in 1934 added his own material to Kocbek's collection. In the second half of the 20th century three publications were published by Stanko Prek (1972), Marija Makarović (1973) and Etbin Bojc (1974), the latter being the most important. The Institute of Slovene Ethnology is preparing a new up-dated publication. Unfortunately Slovene researchers have not yet dealt with this subject matter thoroughly.
\end{abstract}

Keywords: proverbs, folklore collection, Slovene folklore, Slovene protestantism, paremiology

There is a very short way from a language that already comprises established groups of words to the smallest composed units of literary folklore, to similes, sayings and proverbs. ${ }^{1}$ People try to express some personal insight in an impersonal way or their agreement with an objective truth economically and as shortly as possible. Sayings and proverbs are the longest linguistic units that can still be itemised in dictionaries; therefore it is not surprising that within the basic ethnological survey ${ }^{2}$ they are classified under a special heading in the chapter on language.

1. Many proverbs can already be found in the Slovene Protestants' introductions to different chapters of the Bible, especially in those written by Primož TRUBAR, the father of the Slovene book (1550), ${ }^{3}$ and Jurij DALMATIN, who translated the Bible into the Slovene language (1584). ${ }^{4}$ But the first among Slovene Protestants

${ }^{1}$ From the linguistic aspect Jože TOPORIŠIČ calls them phraseologems. Cf. J. TOPORIŠIČ, K izrazju in tipologiji slovenske frazeologije, Jezik in slovstvo 19 (1973/74), 273-279.

2 Vilko NovAK, Slovenska ljudska kultura, Ljubljana 1960, 243.

${ }^{3}$ Primož TRuBAR, Catechismus Jn der Windischen Sprach ... Anu kratku podvučene s katerim vsaki človek more v nebu priti, 1550. Abecedarium vnd der klain Catechismus in der Windischen Sprach. Ane bukvice, iz tih se ti mladi inu preprosti Slovenci mogo lahko v kratkim času brati navučiti ... 1550.

${ }^{4}$ Primož TruBAR, Iz razlage XVI. Poglavja Apokalipse, in: Mirko RuPEL, Slovenski protestantski pisci, Ljubljana 1966, 264. 
who gave special attention to proverbs and sayings was the author of the first grammar book of the Slovene language (Articae Horulae, 1584) $)^{5}$ Adam BOHORIČ. He included twenty-two of them in the chapter on syntax, but the question arises whether these proverbs are of Slovene ${ }^{6}$ origin, as are Slovene the words in which they are written down, or translations, let us say calque translations from Latin, the language of the first Slovene grammar, or they even result, at least some of them, from his own insights. Considering the fact that they are written in the mentioned classical language first and then in Slovene, it is more likely that they derive from Latin. On the other hand, it can be claimed that BOHORIČ wanted to present in his Articae Horulae not only the living Slovene words and rules that connected them into meaningful sequences of thought, but also sentences that expressed the thoughts of their bearers.

Whatever the origin of these proverbs and sayings, at least some of them are also Slovene property - as the result of folklorization. Common people are unlikely to read the books in which the proverbs were written for the first time. They heard one or another when meeting the nobility, and for the most part probably from the pulpit. With the vocabulary and sentences from everyday life and work, the paremiologic contribution in the BOHORIČ's grammar is a unique document of the secular thought of the Slovenes in the 16th century. It is the result of their own experience and understanding, day by day verified in the relations with their fellows or superiors, and in their contacts with nature. It was not by chance that BOHORIč liked to resort to this miniature folkloristic genre when explaining the grammatical rules of the Slovene language. Hieronim MEGISER's Paromiologija ${ }^{7}$ is another proof that Slovene was greatly respected at that time. In 1592 he published his first edition and in 1605 a revised edition of proverbs and sayings in the Greek, Latin, Italian, French, German, Hebrew, Turkish, Arab and other languages. He also included about twenty proverbs in 'sclavonisch'. ${ }^{8}$ It is disputable whether these proverbs are Slovene, as RADICS thought, or Croat. ${ }^{9}$ In any case, some of them are Slovene..$^{10}$ However, there are still many questions to be answered in relation to the proverbs from the time of the first Slovene secular publications.

2. It seems that in the time of the restoration of the Roman Catholic Church and Counter-Reformation, people were already aware of the importance of proverbs, as testifies a Capuchin friar's exclamation from that time, "Malu besedi brez pripuvist, malu govorjenja brez perglih." ${ }^{11}$ (Not many words without proverbs, not much talk-

${ }^{5}$ Adam BOHORIČ, Articae Horulae, Wittenberg 1584.

${ }^{6}$ When the adjective Slovene is used, it is always conditionally because in that time the national consciousness in today's meaning had not yet been formed. Cf. D. SEGA, Med Biblijo in Cerkovno ordningo, in: P. TRUBAR, Slovenska cerkovna ordninga, Ljubljana 1975, 116.

${ }^{7}$ Hieronim MEGISER, Paromiologija, 1592.

${ }^{8}$ P. pl. RADICS, Zbirka pregovorov iz leta 1592, Kres II (1882) 332-334.

${ }^{9}$-r, Zbirka slovenskih pregovorov iz leta 1592, Ljubljanski zvon II (1882) 562-564

${ }^{10}$ This is M. RUPEL's opinion. Cf. Slovenski protestantski pisci, op. cit., 453.

${ }^{11}$ Mihael KRAMMER = Rogerij LJUBLJANSKI, Palmarium empyreum II, Klagenfurt 1743, 166. 
ing without parables.) Considering the fact that Janez SVETOKRIŠKI ${ }^{12}$ and Rogerij LJUBLJANSKI almost always express their sententious thoughts in Latin before repeating them in Slovene, a special study of the sources of those proverbs that seem familiar today would be needed. It is somehow uncertain whether all the proverbs quoted in their works are of Latin origin or the opposite direction could also be taken into account, namely that one or the other among them results from local experiences and they Latinized it for the occasion, for its literary use. The formal differences are only consequences of linguistic and cultural changes in our country. Jernej BAZAR actualises in a most vivid way the function of proverbs for eschatological purposes, but at the same time in a most realistic interpretation. “... ostane tedaj resnično, de boš dobro smrt sturil, če boš dobro živel. Kar boš sejal, to boš žel. Dokler kakršen sejanek takušni sad." ${ }^{13}$ (It is true then that he dies happily who lives a good life. As you sow, so you reap. Therefore, good seed makes a good crop.) Janez SVETOKRIŠKI sometimes expresses himself so that his teaching would be as true and real an example as possible. "Nizku nizku misli moje danes ostanite, zakaj ta, kateri previsoku se povzdigne pregloboku pade. Ikarus zakaj prevzetnu do sonca je hotel leteti, $v$ tu globoku morje je bil padu." ${ }^{14}$ (Do not be ambitious today, my thoughts, as pride will have a fall. Icarus pridefully wanted to reach the sun and he fell into the deep sea.)

VALVASOR's Slava vojvodine Kranjske ${ }^{15}$ (In Praise of the Duchy of Carniola) includes many a saying, but several times the Latin quotation tells where it comes from. However, there is no doubt about the Slovene origin of a proverb when circumstances are described in which a particular proverb is applied or when, exceptionally, it is also cited in Slovene. VALVASOR, for example, somehow amusingly explains why it is said that in the town of Kranj, there is more wine than water; and why the people of Šmartno in Dolenjska prefer wine to water. He says that they stick to the proverb, "Riba v tretji vodi je strup." (A fish in the third water is a poison.) Therefore they rather want it to swim in wine. "Kjer ni vina, ni veselja." (No wine, no joy.) And he praises Dolenjska, which, as a wine-growing region, has no right to complain that enjoyment is lacking. ${ }^{16}$ The following proverbs involve human nature and character. "Prevzetnost hodi pred padcem." (Pride goes before the fall.) "Vsaka trdnjava se more osvojiti, če le more z denarjem obložen osel vanjo." ${ }^{17}$ (Every fortress can be conquered if only a donkey loaded with money can get into it.)

3. At least sixteen letters ${ }^{18}$ written by Jenej KOPITAR are known to which "domestic phraseology, clichés, sayings and proverbs are interwoven". KOPITAR, one

12 Tobia LIONELLI $=$ Janez SVETOKRIŠKI.

13 Jernej BASAR, Consiones iuxta libellum Exercitiorum S. P. Ignatii-Pridige iz bukvic imenuvanih Exercitia ..., 1734, 473.

14 Janez SVETOKRIŠKI, Sacrum promptuarium - Sveti priročnik I, Venezia 1691, 101.

15 Janez Vajkard VALVASOR, Die Ehre der Herzogthums Krain, 1689.

${ }^{16}$ Valvasorjevo berilo (Readings from Valvasor, Second and revised edition, ed. Branko REISP), Ljubljana 1969, 34, 40, 49, 50, 88, 89, 131, 334, 335.

17 Valvasorjevo berilo, op. cit., 142, 143, 358

${ }^{18}$ Stane SUHADOLNIK, Kopitarjeva (dopisovalna ) slovenščina, Slavistična revija 29 (1981) 171-186. 
of the greatest Slavists of all time and author of the first scientific grammar of the Slovene language, ${ }^{19}$ felicitiously makes use of proverbs in his examples of the use of relative pronouns. "Kdor naravnost hodi, hodi brez skrbi. Kdor pa s poti zavija, bo očiten postal." (Who goes straight forward has nothing to worry, but who goes out of the right way will draw attention.) "Komur se šibe škoda zdi, sovraži svojega sina, kdor ga pa ljubi, ta ga vedno strahuje." ${ }^{20}$ (Who spares the rod hates his son, and who loves him never spares the threat.) Baron Žiga ZoIs, the maecenas of the Slovene Enlightenment, a poet, critic and translator, was also aware of the practical aspect of proverbs. ${ }^{21} \mathrm{He}$ did not only collect and write them down, but also included them accordingly into his Slovene writings, which is a proof that he had a good knowledge of the Slovene language..$^{22}$ Similarly, the first Slovene dramatist Anton Tomaž LINHART $^{23}$ recognised their stylogenic function. Janez N. PRIMIC included in his Nemško-Slovenska branja ${ }^{24}$ more than fifty proverbs under a special heading, but they can be found here and there throughout the book. He left sixty-seven other proverbs in his manuscript remains. ${ }^{25}$

Janez MiHELIČ compiled the first proper collection of Slovene proverbs. ${ }^{26}$ It comprised over one hundred proverbs collected in Dolenjska and Gorenjska. MIHELIČ became interested in proverbs in the renascence circle of the Augustinian friar Marko PoHLin. According to J. KorUZA, Mila pesm, katiro je $J^{*} M^{* *}$ [Janez Mihelič $k^{\prime}$ hvalli the pregovorov pejl27 (The gentle poem with which $J^{*} M^{* *}$ praised these proverbs) (1779) was evidently intended for the introduction to the collection of proverbs. The introduction is divided into three parts, the first of which is closely related to the title, the second praises father M. PoHLIN as a mentor, and the third is the very introduction to the foreseen collection. From this poem and Pohlin's versified answer (Wytestka pesm, katiro je zložil $P^{*} M$. $^{*} D$. *, enemu za odgovor, katire je njemu na čast hvallo the pregovorov pejl28 / Chivalric poem written by $P^{*} M . * D . *$ in reply to the one who praised these proverbs in his honour) some conclusions with regard to the collection itself can be drawn. ${ }^{29}$ PoHLIN says in his Bibliotheca Carnioliae (1803) that the manuscript of Slovene proverbs is ample and that editing and publishing it would be to the advantage of Slovene literature. That was the last notice referring to the first major collection of Slovene proverbs. ${ }^{30} \mathrm{~J}$. KOPITAR and Ž. ZOIS already supposed that, unfortunately, the collection had been lost when they tried

\footnotetext{
19 Jernej KOPITAR, Grammatik der slavischen Sprache in Krain, Kärnten und Steyermark, 1808.

20 Jernej KOPITAR, op. cit., 296.

21 Alfonz GsPAN, Tri nova Zoisova slovenska pisemska besedila, Slavistična revija 2 (1969) 119-181.

22 Alfonz GsPAN, op cit., 53, 120, 122, 146, 159.

23 Jože PoGAČNIK, Zgodovina slovenskega slovstva, II, Maribor 1969, 100.

24 Janez N. Primic, Nemško - Slovenska branja, ... Nemški Gradec, 1813, 79-86.

25 Janez N. Primic, Rokopisna zapuščina, MS 361, Mapa L, ovoj 1, lista A in B, Narodna in univerzitetna knjižnica Ljubljana.

${ }^{26}$ France KIDRIČ, Zgodovina slovenskega slovstva, Ljubljana 1929-1938, 177.

${ }_{27}$ Pisanice od lepeh umetnosti I, II (Miscellany of the art of writing), Ljubljana 1779 and 1780, 6-10.

${ }_{28}$ Marko PoHLIN, Pisanice. Cf. Note 27.

${ }^{29}$ Jože KorUZA, Pisanice od lepeh umetnosti (Cf. Note 27), Facsimile, Introduction, 28-29.

${ }^{30}$ Dušan MAHKOTA, Pohlin literarni zgodovinar, Slovenski jezik III (1940) 73-83.
} 
to give a satisfying reply to J. Dobrovski, who in 1809 wrote to KOPITAR in Vienna. He was interested whether Carniolians had a "published collection of proverbs". ${ }^{31}$ Consequently, it can be said that the oldest collection of Slovene proverbs is preserved in the grammar and dictionary ${ }^{32}$ written by Ožbalt GUTSMAN ${ }^{33}$ in 1777. Ivan GRAFENAUER has closely examined the origin of these proverbs. ${ }^{34}$

Urban JARNIK included about one hundred proverbs in his book of fine teachings for young people $(1814)^{35}$ with a comment that they had been translated from the Czech language. ${ }^{36}$ Another collector, Franc A. BRECKERFELD recognised proverbs as the expression of national philosophy. ${ }^{37}$ Jakob ZUPAN $^{38}$ collected them as well. At least some 120 proverbs, sayings and other linguistic formulas have been preserved in the manuscript remains of Franc BILC, ${ }^{39}$ that is in all three parts of his Collectio vocabulorum. To explain some of them he helps himself with German and to explain others he uses Italian. For now, a satisfactory explanation why he classified part of them under the heading Proverbi illirici ${ }^{40}$ still cannot be given. It seems that his choice is related to the administrative organisation of provinces in that time, as testifies also the title of the Franc METELKO's grammar Lehrgebäude der slowenischen Sprache im Königreiche Illyren und in den benachbarten Provinzen (1825). In METELKO's manuscript remains 208 numbered linguistic formulas collected under the title Kranjski pregovori ${ }^{41}$ (Carniolian proverbs) have been preserved. Most of them in fact are proverbs, and some are the so-called popular sayings and other kinds of phrases. METELKO assigned them an important role in his grammar, as he considered them under three headings. The examples under the first heading are cited in German in the first place and then in Slovene. The second part is dedicated to sayings, which are explained in German, in the second place. Similarly, the examples of proverbs are translated or explained in German. There are 53 sayings and 120 proverbs, which is less than in the manuscript, but there are also some others that cannot be found in the manuscript. In any case, the listed Slovene phraseology that was added to his grammar served its purpose because some of it appeared also in poetry. ${ }^{42}$

${ }^{31}$ France KIDRIČ, Zgodovina slovenskega slovstva, op. cit., 412.

32 Windische sprachlehre, verfasset von Oswald GUTSMANN, kaiskönigl. Missionarien in Kärnten ... Klagenfurt, gedruckt bey Ignaz Aloys Kleinmayer, landschaftlichen Buchdrucker, 1777.

Deutsch-windisches Wörterbuch mit einer Sammlung der verdeutschten windischen Stammwörter, und einiger vorzüglichern abstammenden Wörter. Verfasset von Oswald GUTSMANN, Weltpriester ... Klagenfurt 1789.

${ }_{33}$ Milko MATIČETOV, Pregovori in uganke, Zgodovina slovenskega slovstva I, Ljubljana 1956, 116.

${ }^{34}$ Ivan GRAFENAUER, Gutsmanov besednjak in njegova zbirka pregovorov, rekov in prilik, in: Literarnozgodovinski spisi, Ljubljana 1980, 529-551.

35 Vilko NOVAK, Urban JARNIK, Raziskovalci slovenskega življenja, Ljubljana 1986, 131.

${ }^{36}$ Urban JARNIK, Zber lepih ukov za slovensko mladino, Celovec (Klagenfurt) 1814, 100 Pemskih Pripovesti na Slovensko prerovnanih, 102-106.

${ }^{37}$ France KOTNIK, Pregled slovenskega narodopisja, Narodopisje Slovencev I, Ljubljana 1944, 26.

38 France KIDRIČ, Dobrobsky in slovenski preporod njegove dobe, Ljubljana 1930, 174.

${ }_{39}$ Manuscript remains of Franc BILC, MS 430, Bilziana, Collectio vocabulorum pro lexiko Vodnikiano,

1., 2., 3., Narodna in univerzitetna knjižnica Ljubljana.

40 Cf. Note 39.

${ }^{41}$ Manuscript remains of F. METELKO, MS 562, 1, Narodna in univerzitetna knjižnica v Ljubljani.

42 Jože POGAČNIK, Zgodovina slovenskega slovstva II, op. cit., 134. 
4. While proverbs are scattered only here and there in the writings of other authors of the time, there are plenty of them in the works of Anton Martin SLOMŠEK (1800-1862) ${ }^{43}$ Life principles, centuries old human experiences and popular wisdom expressed in picturesque similes, sayings and proverbs were just what Slomšek's pedagogical talent needed. "Prislovice ali sploh pregovori so zlati orehi za življenje; pa učitelj je dolžen deci jedro razluščiti. (Sayings and proverbs in general are golden nuts for life; but the teacher must disclose the core to children.) ... Jabelko je zjutraj zlato, opoldne srebro, zvečer pa svinčeno ... Je že kdo otrok to videl? Videl ni, skusilo jih je veliko. Če sadje zjutraj uživaš, ti bo dobro služilo in je zlata vredno. Manj zdravo je opoldne, na večer ti bode želodec kakor svinec. ${ }^{44}$ (An apple is gold in the morning, silver at noon, and leaden in the evening ... Has any child seen that? Of course not, but many have experienced it. If you eat fruit in the morning, it will do you good and is worth gold. It is less salutary at noon, and in the evening your stomach will be like lead. Cf. 'An apple a day keeps the doctor away.') ... Kratki in krepki so slovenski pregovori in prislovice, žlahtnim jagodam v kiti govora podobne." 45 (Short and pithy are Slovene proverbs and sayings and they are like precious beads in the bunch of speech.) No other literary folklore he appreciated as much and he never lost sight of the educative effect of proverbs, but he was aware of their great value for linguistics as well. To a modern patriot "genuine words and proper sayings ... are precious pearls with which he enriches the treasure of his language as long as he can." SLOMŠEK does not use proverbs and other forms of formulative expression for aesthetic purposes as much as for the reason of their practical illustrativeness. This is proved by the fact that he uses the same proverb in different places. His ability to prepare the context for the communication of some life principle or teaching can also be attributed to SLOMŠEK's pedagogical talent. ${ }^{46}$ There are so many proverbs scattered all over his writings and they are driven so close to the farming folks mind that often their roots can hardly be distinguished. Perhaps SLOMŠEK himself gives us the key. No doubt proverbs do not result from his own efforts when he explicitly refers to them. For example: "Star pregovor pravi: Kar dobri ljudje radi imajo, tudi Bog rad ima. (An old saying goes: What good people like, God likes as well.) Pa tudi, kar Bog z eno roko vzame, $\mathrm{z}$ dvema rokama ljudem da. (And also that what God takes with one hand he gives to people back with both hands.) In ako le hočemo prav spoznati in se podati v sveto volj božjo, se prav lehko prepričamo, da kar Bog stori, vse prav naredi." ${ }^{\text {47 }}$ (And if only we are willing to know and follow the Holly Will of God, we can easily recognise that whatever God does, he does it right.)

${ }^{43}$ Anton Martin SLOMŠEK, a priest, bishop, poet, writer, editor, national awakener and educator. The process for his beatification ended in May, 1998. In September 1999 he was beatified.

${ }^{44}$ Anton Martin SLOMŠEK, Zbrani spisi IV (Collected Works IV, collected, edited and published by Mih. LENDOVŠEK), Celovec (Klagenfurt) 1885, 33.

45 Anton Martin SLOMŠEK, op. cit., 259.

${ }^{46}$ Anton Martin SlOMŠEK, Zbrani spisi II (Collected Works II, Fables, Parables and Tales, collected, edited and published by Mih. LENDOVŠEK), Celovec (Klagenfurt) 1878, 220.

${ }^{47}$ Anton Martin SLOMŠEK, Zbrani spisi III (Collected Works III, Biographies, collected edited and published by Mih. LENDOVŠEK), Celovec (Klagenfurt) 1879, 30, 273. Zbrani spisi IV, op. cit., 29, 85. 
5. The period of realism was the most fruitful also with regard to proverbs. Gregor KREK tells the public that in the heritage of Stanko VRAZ, a meritorious collector of Slovene literary folklore, besides other things there are a fair number of popular sayings and other literary fragments. ${ }^{48}$ In 1865 Slovenski glasnik informed the readers about the foreseen publication of Polyglott-Parëmiophraseologie oder Wörterbuch der deutschen, lateinischen $u$. griechischen parallel neben einander gestellter Sprichwörter und sprichwörtlichen Redensarten etc. After many years of endeavours the priest Jožef VUK put together a rich collection of proverbs and sayings in the German, Italian, Slovene, French, English, Latin and Greek language. There was also an invitation stating that the price of the dictionary will depend on the number of subscribers ${ }^{49}$ There is no evidence that this multilingual collection was really published. Were there too few subscribers? Fran ERJAVEC evidently had in mind a dictionary of Slovene phraseology ${ }^{50}$ during his travels and field explorations.

Vojteh KURNIK from Tržič first published about sixty ${ }^{51}$ and then eighty-three proverbs and sayings. ${ }^{52} \mathrm{He}$ wanted to publish them in a special collection and it is not clear why he did not. ${ }^{53}$ Janez BILC ${ }^{54}$ and Jakob ŽNIDARŠ $\breve{C}^{55}$ collected proverbs and sayings in Notranjska, and Fran ERJAVEC also mostly in the western parts of Slovenia. ${ }^{56}$ If Jakob VoLČIČ, who was publishing proverbs and sayings from Istria ${ }^{57}$ through several years, may be taken into account as well, it would become evident that the Mediterranean cultural world was much more active in comparison with other Slovene lands. The proverbs of the Styrian Slovenes that were collected by A. KREMPL were published in the periodical Kmetijske in rokodelske novice from 1844 to $1848 . .^{58}$

A great number of proverbs are preserved in the literature of that time. Jože GREGORIČ $^{59}$ selected at least 275 proverbs and sayings only from the works of Josip JURČIČ. A separate study could be made to examine the function of proverbs in the works of this most important writer of the Slovene realism. In that time, the awareness of 'being old' as a positive qualifier with regard to proverbs began to grow. Cf. "Stari pregovor pravi ..." ${ }^{60}$ (As the old saying goes ...) "Star pregovor pravi ..." ${ }^{61}$ (An old proverb says ...) "Saj da 'črka le mori, duh pa živi! je star pregovor. Zakaj bi ravno pri nas ne veljal?" 62 (That the words kill, but the spirit revives is

48 G. KREK, O Vrazovi ostalini, Letopis Matice slovenske 1871, 29.

${ }^{49}$ Polyglott-Paremiophraseologie, in: Slovenski glasnik (1865) 222.

${ }^{50}$ Fran ERJAVEC, Iz potne torbe, in: Letopis Matice slovenske 1875, 218.

51 Cf. Šolski prijatelj 4 (1855) 31-32.

52 Cf. Slovenski glasnik (1851/I) 108-110.

53 F. KOCBEK, Pregovori, prilike in reki, Ljubljana 1887.

54 Cf. Slovenski glasnik (1858/I) 86.

55 Cf. Slovenski glasnik (1858/I) 23.

${ }^{56}$ Fran ERJAVEC, Iz potne torbe, in: Letopis Matice slovenske, Ljubljana 1883, 195-351.

57 Cf. Slovenski glasnik (1858/II) 54, 69-70, 91, 181; SG 1859, 154, SG 1860; SG 1868, 98.

58 From 1844, No. 10 to 1848 , No. 7.

59 Jože GREGORIČ, Ljudska modrost v Jurčičevih spisih, in: Književni glasnik Mohorjeve družbe (Celje 1981) I, 8-11; II/III, 26-28.

${ }^{60}$ Agrež, Spoštuj svojo mater, in: Drobtinice 11 (1856) 196-197.

${ }^{61}$ J. NAVRATIL, Kar je pošteno, nar dalje trpi, Vedež (1849) 99-100.

${ }^{62}$ Cf. J. MARN, Jezičnik 20 (1882) 25. 
an old saying. Why should it not apply to us?) "Tako glejte otročiči: 'kdor ne uboga, je brez Boga', in 'po slabi tovarišii rada glava boli' - pravita že stara pregovora." ${ }^{63}$ (So listen, my little children: 'he that does not obey is without God', and 'bad company leaves bad headache', say even these two old proverbs.) "Saj je znan star pregovor, da veliko glav več ve in da skušnje so stopinje, po katerih napreduje vsaka stvar ...." ${ }^{64}$ (You certainly have heard the old proverb that two heads are better than one and that experience is a step by which everything goes forward. [Cf. 'Experience is the best teacher.']) J. NAVRATIL writes that F. MIKLOŠIČ is very pleased if respectable men examine his books. F. MiKLOŠI ̌ knows that 'all people know all'. F. MIKLOŠIČ even says (and it is a proverb to him) that only immense stupidity has no need to amend anything. ${ }^{65}$

One of the most difficult tasks in studying proverbs is their systemisation. The major contribution in this regard has been Viljem URBAS' $O$ pregovorih in prilikah, sosebno slovenskih (1869). ${ }^{66}$ First he gives definitions and quotes different opinions on proverbs from the times of ancient thinkers onwards. He speaks of the importance of proverbs for each national or language community because they express also the spirit of the community. URBAS also enumerates, according to his opinion, the most important collections of proverbs among the Slav nations. As to their form he distinguishes proverbs, parables, wise sayings, slogans, and proverbial phrases, which "express a wise thought, but in an amusing way". Then he outlines their relation to other kinds of literary folklore (fairy tales, tales etc.). According to their function, he groups them into those that show the world as it is (they are images of human activity), and others depicting the world as it should be (life principles). Proverbs and parables about man and his character, (in)abilities and about the native country are then classified under ten headings. They are taken not only from literary folklore, but also from literature. They are accompanied by the author's comments on their background and origin, on different forms of the same thought and on circumstances in which one or another proverb / parable is appropriate. The discussion was published in twelve series in the Bleiweis' periodical Novice in 1869 and $1870 .{ }^{67}$ But why 'Matica slovenska' did not publish his collection of Slovene proverbs remains an open question. ${ }^{68}$

In 1883 a booklet $(8 \times 12.5 \mathrm{~cm})$ of fifty pages entitled simply Pregovori was published in Vienna. 'British and Foreign Bible Society' appears on the title page, from which it is evident that it is the biblical Book of Proverbs. ${ }^{69}$ Finally, in 1887, the first

63 Šemrl, Pošteni oče in malopridni sin, in: Šolski prijatelj 1 (1852) 372.

64 Cf. J. MARN, Jezičnik 20, 1882, 21.

${ }^{65}$ Cf. Slovenski glasnik 1859, 98, 99

${ }^{66} \mathrm{O}$ pregovorih in prilikah, sosebno slovenskih, Jahrbericht der K. K. Ober-Realschule in Goerz (1869) $2-33$.

${ }^{67} \mathrm{O}$ pregovorih in prilikah, sosebno slovenskih, Spisal profesor Vil. URBAS, Novice gospodarske, obrtniške in narodne, (in the issues from September, 1869 to March 1870).

${ }^{68}$ Fran KocBEK, Pregovori, prilike in reki, Ljubljana 1887, 93.

${ }^{69}$ A comparison with the Book of Proverbs in the ecumenical Slovene edition of the Bible (Ljubljana 1985) shows that here some sections had been left out. The chapters are only numbered and have no titles. However, the final number of sections in both editions is equal, that is 31 . 
collection of Slovene proverbs Pregovori, prilike in reki was published. In the introduction Fran KOсBEK enthusiastically exclaims, "There you are the first collection of Slovene proverbs, parables and sayings!" 70 At the end the sources are quoted, but in the introduction the author claims that he found them also among the people. He considers his booklet the basis "for the future collecting of this kind of popular pieces." "11 "Proverbs are the treasures of human wisdom," continues KoCBEK. ${ }^{72} \mathrm{He}$ also discusses their function and poetics. ${ }^{73}$

6. In the time of transition from the 19th to the 20th century, the collecting of proverbs is represented only by one publication..$^{74}$ But the editors of a periodical for children entitled Vrtec proved to have considerable interest when in 1900 they began to publish interpretations of proverbs. An unknown author first tries to explain the circumstances in which proverbs were created and teaches young readers to look carefully at the language and its poetical power of expression. He also explains that in most cases a metaphor or metonymy is in question. Then he applies the dominant idea to the contemporary life. Dozens of proverbs are explained in such way and there are several among them that sound quite unfamiliar ${ }^{75}$ to us today. In accordance with the pedagogical objectives of the periodical, the non-identified author tries to make children understand the positive psychological characteristics and values through proverbs. As it appears, he has adult readers in his mind as well because he openly says that he himself does not like the slavish fear of the rod. The unknown author of this proverb series paid much attention to the semantics of this miniature folkloristic genre, but theoretically he hardly said anything. ${ }^{76}$

7. In the period of expressionism it was Ivan ŠAŠELJ who promoted proverbs most successfully. In 1910, he published collected proverbs and sayings ${ }^{77}$ in Bisernice. He went on with his collecting and continued publishing proverbs in Dom in svet. ${ }^{78}$ The attitude towards his work is perhaps the best illustration of the fact that literary folklore in Slovene publicism was gradually turned to the sidetrack until it completely disappeared from it. Publishing of the material was limited to the smallest pieces of literary folklore, to proverbs and sayings, and even these appeared only on covers ${ }^{79}$ Finally they withdrew from there to other, locally profiled reviews, such as Mladika $^{80}$ in Gorizia.

\footnotetext{
${ }^{70}$ Fran KoCBEK, Pregovori prilike in reki, Ljubljana 1887, III.

${ }^{71}$ F. KOCBEK, op. cit.

72 F. KOCBEK, op. cit.

73 F. KOCBEK, op. cit.

74 Janko (BARLE? ViJANSKI?), Narodno blago, Dom in svet 11, 1898, 384. Cf. p. 288.

75 Vrtec 30, 1900; Vrtec 31, 1901; Vrtec 32, 1902, Vrtec 33, 1903; Vrtec 34, 1904.

76 Vrtec 31, 1901.

77 Ivan ŠAŠELJ, Bisernice iz belokranjskega narodnega zaklada, I, 1906, 1-16; II, 1909, 3-6.

${ }_{78}$ Belokranjski pregovori in reki, written down by I. Š. Dom in svet 24 (1911) 164; 29 (1916) 52; 31 (1918) 168; 33 (1920), on covers 9-10; Dom in svet (1929) 48.

79 At the turn of the century the same happened first to the fairy tales of Gašper KRIŽNIK and poems of Jurij VODOVNIK, also in the major periodical Ljubljanski zvon.

${ }^{80}$ Narodni pregovori in reki written by J. Ś. ... Mladika 7 (1926) 310, 348, 428; 8 (1927) 435; 10 (1929)
} $227-228$. 
8. During the period of social realism, a collection entitled Slovenski pregovori, reki in prilike was published in 1934. The names of the authors prove that this is an enlarged edition ${ }^{81}$ of KOCBEK's collection from 1806. The co-author of the collection in question is Ivan ŠAŠELJ. ${ }^{82}$ Here the parables are put at the end, which agrees with the reasoning of modern times when the sense of the close relationship between parables and proverbs has been completely lost. The foreword to the collection was written by Veselin ČAJKANOVIĆ, the most respected Yugoslav specialist in proverbs of the time. He distinguishes two kinds of proverbs: (1) proverb, sententious saying, in which some truth is stated directly or in an allegory ${ }^{83}$ Proverbs are primarily of international character and therefore their cultural and historical value is limited and they have no particular internal power. The popular wisdom in proverbs, so often praised, is neither original nor profound, claims ČAJKANOVIĆ. It is the form, the way in which we want to generalise this or that truth by telling 'communia proprie', that gives a proverb its value. (2) Metaphor, allusion to a commonly known event that has been talked about or just happened. ${ }^{84}$ According to ČAJKANOVIĆ, metaphors, which are more or less limited in time, have considerably greater cultural and historical importance.

Because of its "freshness and variety" he considers the collection one of the most wonderful in our folkloristic literature that will be to advantage of scientists and the general public. ${ }^{85}$ Besides the literary value Slovene proverbs have also a high historical, ethnological, that is to say scientific value. ČAJKANOvIĆ proves it with a few examples. The proverb 'Gost v hišo, Bog v hišo' (A guest into the house, God into the house) involves an ancient belief. Also among primitive peoples there was a deeply rooted belief that from time to time a divinity in the image of man, disguised as a traveller or a beggar comes to the homes of mortals. This belief produced numerous tales of divinities or saints who visited and tried people and then rewarded the good and punished the wicked. ${ }^{86}$ Practically, such beliefs encouraged hospitality because every guest was seen as a probable manifestation of a divinity. In the quoted Slovene proverb there might be some traces of that ancient belief, probably with the backing of Christianity. (Cf. Matt. 25, 35; Heb. 13, 2.)

9. Almost twenty years had passed before proverbs were given attention once again. That was in 1952 when Ivan GRAFENAUER defined them as "the shortest form of popular poetry, the more or less artistically articulated ornaments of popular lan-

81 The collection comprises 5624 proverbs, among which 575 are about the weather.

82 Slovenski pregovori, reki in prilike. Collected by F. KOCBEK and I. ŠAŠELJ, Celje 1934.

${ }^{83}$ For example: 'Proti vodi se ne da plavati' (You cannot swim against the stream.) 'Kdor ne seje, ne žanje.' (If you don't sow, you can't reap. Cf. If you won't work you shan't eat.) 'Nova metla dobro pometa.' (New broom sweeps clean.) Op. cit., 6.

${ }^{84}$ For this kind of proverbs he quotes examples from the ancient world: Crying like Nanac; Endymion's sleep; Born on the fourth day; Amaltea's horn.

85 Veselin ĊAJKANOVIĆ, Predgovor, in: Slovenski pregovori, reki in prilike, Celje 1934, 5.

${ }^{86} \mathrm{Cf}$. the classical myth of Philemon and Baucis, Goethe's poem Gott und Bajadere, Grimm's tale Der Arme und der Reiche, Serb popular song of the rich Gavan's bride. 
guage, as everyday poetry." ${ }^{87}$ He refers to ČAJKANOVIĆ when speaking of Slovene proverbs as sententious. But when he traces their roots in the ancient times, in the Bible, and finds their medieval parallels, in terms of methodology, he becomes completely independent. ${ }^{88}$ There are also proverbs from the genuine Slovene life and thinking and among them an amusing finding that in Ljubljana, people whiten turnips with a knife instead of fat. ("V Ljubljani repo $\mathrm{z}$ nožem belijo namesto $\mathrm{z}$ mastjo." ${ }^{89}$ Even some passages from Slovene poets have become proverbs. ${ }^{90}$

Scientific research of our proverbs has not made enough progress, admits GRAFENAUER, although the KOCBEK-ŠAŠELJ's collection facilitated it considerably. He suggests that the material should be completed with examples from literary heritage, especially from older works, classified according to the keyword and regionally distinguished. In this way many distorted proverbs could be restored to a more original and better form. Proverbs became distorted with use by passing from one mouth to another, or their contents became hardly understandable because of the changed cultural background. Our proverbs need to be studied thoroughly with regard to the ancient, biblical and medieval proverbs and to those in other languages. Our rhythmical proverbs should be studied also in respect of their rhythmical forms, and all of them with respect to their ethic, ideological, cultural and historical contents, concludes GRAFENAUER.

In 1956, Milko MATIČETOV briefly discussed proverbs as well. His statements are concise and of great value: a proverb means general truths, ${ }^{91}$ polite instructions, ${ }^{92}$ jokes and more or less good-humoured ridicules, ${ }^{93}$ similes, ${ }^{94}$ even very short. ${ }^{95} \mathrm{He}$ does not leave out even the so-called 'wellerisms'. ${ }^{96}$ In proverbs poetry meets and interweaves with philosophy, ethics and thorough knowledge of life. "Whatever the occasion, everybody can help himself with proverbs - the fragments of ancient wisdom (Aristotle) and that is why they have been so popular and important in all times, almost from the times of the first preserved written monuments of humanity. ${ }^{" 97} \mathrm{He}$ points out that they are in fact a genre of literary folklore, but they have a

${ }^{87}$ Ivan GRAFENAUER, Pregovori, in: Narodopisje Slovencev II, Ljubljana 1952, 12.

88 I. GRAFENAUER, op. cit., 14, 15.

${ }^{89}$ It is a word-play: 'Beliti' (dial.) = peel, whiten : 'beliti' = add fat in cooking.

90 I. GRAFENAUER, op. cit., 15.

91 'Navada je železna srajca.' (Custom is an iron shirt. Cf. Old habits die hard. Custom is a second nature.)

92 'Kdor molči, devetim odgovori.' (Who keeps his mouth shut gives an answer to nine. Cf. Speech is silver, but silence is golden.) 'Bolje drži ga, ko lovi ga.' (Better hold it than catch it. Cf. A bird in the hand is worth two in the bush.)

93 'Kar je boljše, je boljše, je rekel tisti, ki je špeh na maslu cvrl.' (What is better is better, said the one who roasted lard in butter.) 'Naglost ni prida, je rekel polž, ki je sedem let lezel na bučo in mu je pod vrhom spodrsnilo.' (Haste is no good, said a snail that had been climbing on a pumpkin for seven years and slipped right under the top.)

94 'Se smeje ko Cigan belemu kruhu.' (He laughs like a Gipsy at white bread.)

95 Rase kot iz vode (Growing as from water) trd ko kamen (as hard as stone) bela ko padeni sneg (white like fallen snow).

${ }_{96}$ These are curtailed stories, like: 'Bomo videli, je rekel ta slep. (We shall see, said the blind.) M. MATIČETOV, op. cit., 115.

${ }_{97}$ Milko MATIČETOV, Pregovori in uganke, in: Zgodovina slovenskega slovstva I, Ljubljana 1956, 115. 
special place and role in the spoken communication. "Maybe the reason is that a proverb can be either a well-represented truth or an allusion to an event that is well known to the collocutor or a politely expressed teaching, a fine irony or a vivid, picturesque allegory, but almost always a short clear-cut and resounding formula. The contribution of rhymes, assonances, alliterations and of the rhythm of words is not insignificant." ${ }^{18}$ What is new in MATIČETOV's discussion is that he gives much attention to the context of proverbs that in Slovenia still prevalently come from farming folk. ${ }^{99}$ As much as we know, among industrial workers specific proverbs have not been formed yet. What Slovene proverbs tell us about different crafts, professions, classes and the like everything derives from rural environment. ${ }^{100}$ MATIČETOV does not forget proverbs about the weather: farming folk's life is closely related to nature and seasons, so a fair number of proverbs involve also the weather and time of the year. Besides proverbs that are quite general and those that fix the time of different kinds of work in the field, forest or at home, there is a whole series of locally limited, but nevertheless very interesting proverbs. They are based on local experiences and observations, for example: 'Kadar pride oblak od Trsta, zmoči za dva prsta; gre od Kopra - bo suknja mokra.' (When the cloud comes from Triest, it wets two fingers deep; if it comes from Capodistria - the jacket will get wet.) 'Mokrc ima kapo, Krim pečo, pa se to skup zvleče - pa je dež.' ${ }^{101}$ (Mokrc has a cap and Krim has a bonnet, then those are drawn together - and it rains.)

10. In 1972 and 1974, after a long time Stanko PREK edited a new popular collection of Slovene proverbs Ljudska modrost, trden je most. ${ }^{102}$ According to his opinion, it is crucial that each proverb includes some value of thought. He was particularly attracted by the pithiness of laconic sentences, clearly expressed life experience and wisdom that is aimed at timeless validity. ${ }^{103}$ PREK introduced 1400 new entries in the second edition, but was too loose in distinguishing the authorial and folkloric dimension in gnomic kinds of proverbs, ${ }^{104}$ for which he was also criticised. ${ }^{105}$

In 1973, a book written by Marija MAKAROVIČ entitled Pregovori - življenjske resnice ${ }^{106}$ was published. With this book something new has been introduced in the discussion. The material is not classified only catalogically and in the alphabet order. Instead, each proverb is presented in the circumstances in which it appeared or might have happened. Therefore it is the attention given to the level of context that is in question. The proverbs are classified under the following headings: Gift/reward, Work/effort, Money/possession, Dowry/inheritance, Hypocrisy/exaggeration/lie/theft, Food/beverages, Cliquism/comradeship, Love/resentment, Peacefulness/patience, Stubbornness/quarrel, Weather/crops, Cause/effect, Health/illness, Ideals/

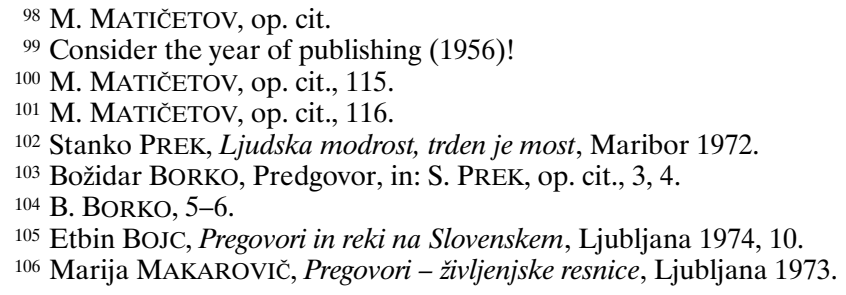


imitations. ${ }^{107}$ In the introduction the authoress refers to the thoughts of I. GRAFENAUER and findings of M. MATIČETOV twenty years before when she presents an important initiative in relation to compiling and completing the collection of Slovene proverbs and their contemporary creation. "How many new, adopted or assimilated proverbs have been collected on Slovene territory in recent times!" 108 As an excellent field worker she carried out an interview concerning proverbs and took occasion to collect many of them. ${ }^{109}$ Consequently she can give an account of the method of work in collecting proverbs. Only a native ethnologist can reliably state their occurrence because the presence of an outside expert draws attention to and may encourage a more frequent use of proverbs in speech. ${ }^{110}$

Etbin BOJC compiled the most comprehensive collection of Slovene proverbs up to that time and entitled it Pregovori in reki na Slovenskem ${ }^{111}$ (1974). In the introduction BoJC praises Slovene proverbs as no one has done before, and then gives a short survey of their collecting. When discussing their function, he refers to the German romanticist J. G. Herder, who already two hundred years ago pointed out the characteristic values of the Slavs. Herder recognised their proverbs as an experienced friend's teaching, a mirror of the nation's way of thinking because they reflected, besides their sagacity and sense, also the rich experiences and customs of a nation. ${ }^{112}$ Proverbs bring to light many significant qualities of a nation, but also many a superstition and unfounded belief. ${ }^{113}$ To facilitate reviewing and searching BOJC decided to classify proverbs according to their contents hoping that in this way his collection of about nine thousand proverbs would be comparable to the contemporary editions of the kind in Europe. The majority of proverbs and sayings in the book retain their rich essence also for the present and future, although they have been collected for the most part in the rural environment of the farming folk. Nowadays these people have already abandoned so many things on the account of industrialisation and information period. There are in fact some proverbs that already are losing their original general meaning and sense. ${ }^{114}$

However, this genre of Slovene literary folklore does exist and generates again and again, conforms and modernizes in place and time.

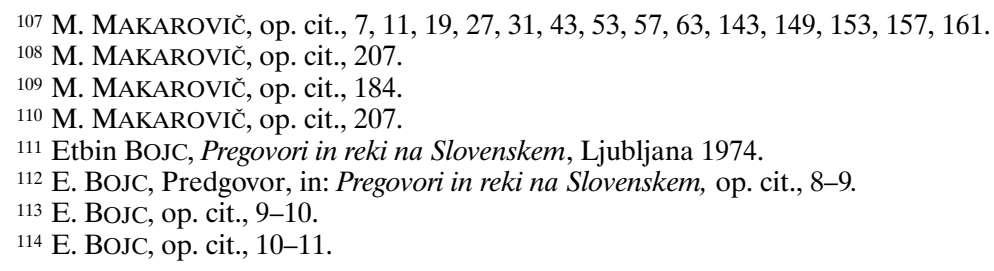

